\title{
Sustainability diagnosis based on indicators for a coastal corridor of the southern Gulf of Mexico
}

\author{
E. Nunez, S. Laffon, A. Alderete \& R. Barreto \\ Dependencia de Ciencias Naturales, Universidad Autónoma del Carmen, \\ Ciudad del Carmen, Campeche, México
}

\begin{abstract}
Indicators were used to evaluate the environmental health of ecosystems and the socioeconomics of human populations along a coastal corridor in a tropical region of the southeastern Gulf of Mexico. A traditional use of natural resources had existed in the region for hundreds of years until the last decade, when a tourist interest began. The positive and negative changes that could be experienced on the environment and human way of life motivated the present research. The main purpose was to carry out an integral sustainability diagnosis and facilitate the resulting information to the stakeholders for proper development planning. The methodology involved: i) the analysis of past and present context of the region in terms of natural resources use; ii) the selection of the suitable indicators according to context; iii) the collection of documented and field data; iv) numerical analysis to relate environmental, social and economic data sets between each other. Environmental indicators showed a relatively healthy environment with particular zones close to the towns showing human alterations and some critical habitat under threat. Residents and tourists have the perception of a good quality and quantity of natural resources and are optimistic about the change of traditional activities to tourism. Social indicators showed a relatively high cohesion among people, but there are evident problems in health, education and wellbeing in general. Economically, indicators show inequality among people and an intermediate level of poverty due to depletion and instability of the incomes from fisheries, agriculture and forestry. Despite that, the change from traditional activities to tourism could represent a socioeconomic benefit, the risk of environmental disturbance exists and the long-term benefits are still uncertain.
\end{abstract}

Keywords: sustainability indicators, coastal ecosystems, tourism, Mexico. 


\section{Introduction}

The coastal zone of the Gulf of Mexico in Campeche State of Mexico is characterized by a high diversity of tropical ecosystems such as mangroves, sandy beaches and rain forest. Part of these ecosystems has been under protection status since 1994 in the "Laguna de Terminos" Natural Protected Area which covers 705,016 has. For hundreds of years, the economy of regional communities has been based on primary productive activities such as fishing, agriculture and forestry. Today it is experiencing a gradual transition to touristic activities, including boating, nature observation and beach recreation. The change in the socioeconomic activities in the last decade has initiated an associated growth in urban infrastructure and human population [1], putting the natural resources under serious pressure. The number of visitors has also noticeably increased, which has associated consequences including an increased release of sewage and pollutants into the environment. Tourism could represent a sustainable way of living for the residents of the small towns of the coastal zones $[2,3]$. However, poor development planning, usually occurring in touristic destinations of Mexico, may not only affect the socioeconomic conditions and cultural heritages of local people but also the preservation of fragile ecosystems.

Sustainability indicators and indices have been used in the last two decades as a useful tool to evaluate individual fields and overall progress toward sustainable development [4]. They are increasingly recognised as measures to evaluate conditions and trends for policy making, strategy formulation and public communication [5]. Indicators help to visualize underlying problems, highlight trends and simplify the interaction between the society and government through the common analysis of experts and stakeholders [6]. The critical selection of the best suitable indicators and indices to apply in an integral diagnostic should take into account important aspects: What is the context of the place to be diagnosed? Where is the spatial limit of the system to be evaluated? What and who is in the system? Sustainability indicators should set basic characteristics i.e. simplicity, quantification, assessment, sensitivity and wide scope to cover environmental, social and economic topics [7].

In Mexico, the National Institute of Statistics and Geography (INEGI) is the agency that integrates, analyses and communicates the data and information about territory, population and economy. Numerous sets of simple and composite data are available through the agency documents, however the accessibility of accurate data at regional or local scale is not always possible, complementary information to accomplish the appropriate indicators is obtained in situ. The purpose of the study was to achieve a comprehensive sustainability diagnosis for a coastal tropical region of the Gulf of Mexico by using an integral analysis of selected indicators. The methodology includes a past-present analysis of the natural resources practises in the region, the acquisition of environmental, social and economic information and the integration of data with multivariate numerical methods. The main question to be addressed was: What is happening to the environment and to humans in the coastal corridor? A systematic assessment about environmental and socioeconomic condition could help 
decision-makers to plan touristic actions and contribute with the policy goals toward sustainable development.

\section{Methods}

\subsection{Study region}

The coastal region studied is located in the southern part of the Gulf of Mexico (Figure 1). It is a tropical corridor in the state of Campeche, Mexico, extending $100 \mathrm{~km}$ along the coastline and $10 \mathrm{~km}$ from the littoral to inland $\left(1000 \mathrm{~km}^{2}\right)$. Half of the study area is inside the "Laguna de Terminos" Natural Protected Area, an estuarine system that comprises a huge extension of wetland ecosystems, mainly mangroves (ca 200,000 has), and other fragile habitats including sandy beaches, seagrass beds and rain forest [8].

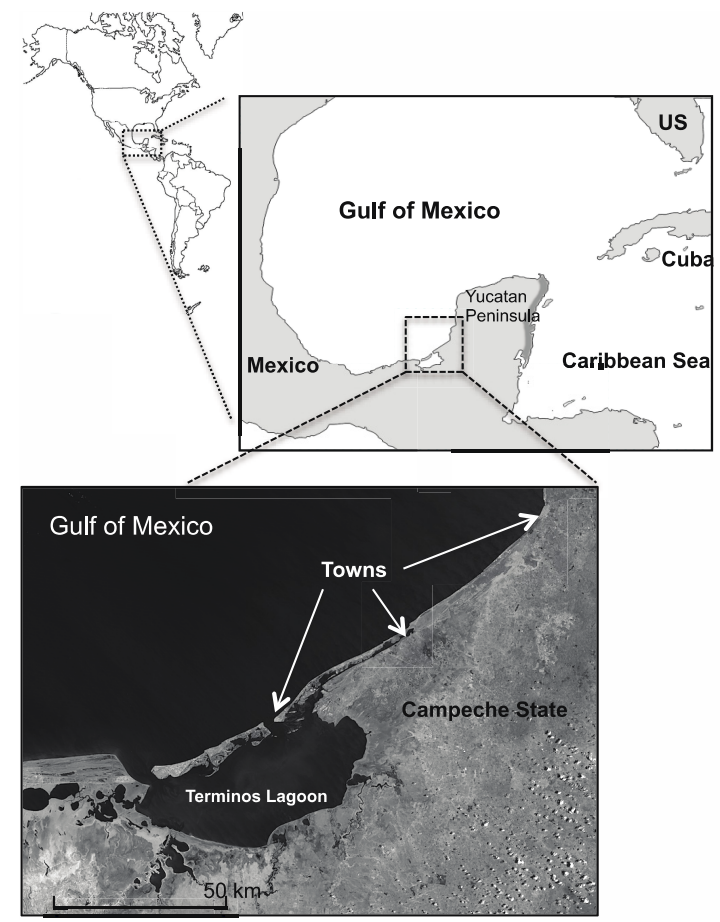

Figure 1: Study region.

There are some emblematical species in the region, including sea turtles, dolphins and manatees, which are in the IUCN Red List of threatened species [9]. Furthermore, it supports a high diversity of birds, fish, amphibians, invertebrates and aquatic plants. Despite the existing environmental norms and the efforts of the local authority to observe the use of natural resources; illegal 
practices are relatively common and the pressures resulting from human activities are particularly threatening.

Three main towns are located within the coastal corridor (Fig. 1): the biggest is Champoton, located in the northern margin of the study area with an approximate population of 30,000. Sabancuy has 3,500 inhabitants in the central sector and Isla Aguada in the southern margin with a population of 2,800. The basic productive activities of the region are fishing, agriculture, forestry and local commerce. The average percentage of population growth from 2000 to 2010 was $1.6 \%$ [1].

Taking advantage of the tranquillity of the towns and the natural and cultural attractiveness of the region, there has been an expansion of touristic activities in Campeche State led by the government for the past two decades. Stakeholders expect low-income communities to benefit within the coastal zone, which is reasonable; nevertheless, infrastructure and services are still limited, e.g. there is not a wastewater and solid management system in the towns and the provision of public water supplies is irregular. The underlying problems, which motivated this research, is that the tourist activities in the coastal corridor could jeopardise the economy of the local populations, the sociocultural traditions and the integrity of the coastal ecosystems due to a lack of appropriate information for planning and management.

\subsection{Sustainability indicators framework}

A literature review was carried out to determine the past context of the region concerning the use of natural resources and the socioeconomic living conditions. This information was qualitatively analysed and used as the criteria to select a primary list of sustainability themes and indicators (Fig. 2). A theme-based

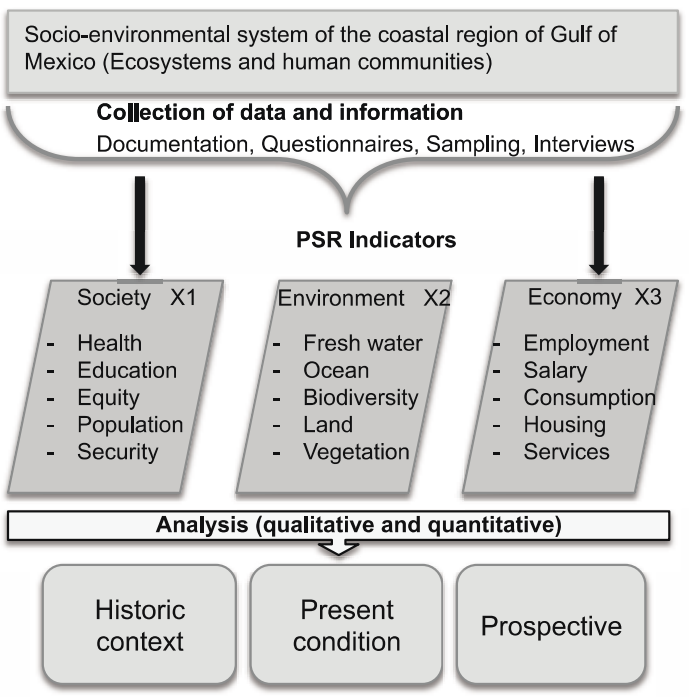

Figure 2: $\quad$ Methodological framework. 
framework was used because of its ability to link indicators to policy target at regional scale [10]. After the selection of indicators, a review of frameworks and published sets of indicators took place [10-12], with particular attention to those to be applied at regional or municipal level $[5,13]$. The expert work team chose an objective set of indicators, aiming to keep to the minimum possible, to facilitate the collection of data within reasonable time and costs, but without affecting representativeness.

\subsection{Survey design and data collection}

The data used to construct the indicators came from national and local public statistics institutions, complemented with data collected in situ (ecosystems and people) obtained by field techniques, household surveys and interviews (Fig. 2). Environmental sampling was conducted in the main aquatic ecosystems (Terminos lagoon, Sabancuy estuary and Champoton river) to construct freshwater and biodiversity indicators. Among the selected sampled species were dolphins, sea birds and sea turtles. Physicochemical parameters of water and sediment were taken on the aquatic ecosystems, including BOD and faecal coliforms.

A student team surveyed the people of the three main communities along the coastal corridor applying questionnaires, designed to be accurate, simple and concise. The questions concerned with the selected themes were planned to be answered on a quantitative or semi quantitative scale to facilitate numerical processing and presentation. The survey sample size varied according with total adult population of the towns; 250 questionnaires for Isla Aguada, 280 for Sabancuy and 350 for Champoton.

\subsection{Interpretative analysis}

Quantitative basic statistics were computed for each of the indicators. The resulting individual values were standardised to a percentage scale that summarised the indicators by dimension. If data, such as under-five mortality, was presented according to the minimum value, i.e. the percentage of children who died before the age of five, the percentage of children who did not die was used in order to fit the scale. The comparative graphics were complemented with a qualitative explanation to extend the interpretation to demonstrate the complexity of the system.

\section{Results}

Ten themes and twenty indicators were included in the final set representing the three dimensions of sustainability (Table 1). 
Table 1: $\quad$ Selected sustainability themes and indicators.

\begin{tabular}{|c|c|c|c|c|c|}
\hline \multicolumn{2}{|r|}{ Society } & \multicolumn{2}{|c|}{ Economy } & \multicolumn{2}{|c|}{ Environment } \\
\hline \multirow[t]{4}{*}{ Poverty } & $\begin{array}{l}\text { Income poverty } \\
\text { and inequality }\end{array}$ & Employment & $\begin{array}{l}\text { Employment } \\
\text { population ratio }\end{array}$ & \multirow[t]{2}{*}{$\begin{array}{l}\text { Oceans and } \\
\text { coasts }\end{array}$} & $\begin{array}{l}\text { Proportion of } \\
\text { marine area } \\
\text { protected }\end{array}$ \\
\hline & $\begin{array}{l}\text { Sanitation } \\
\text { facilities }\end{array}$ & & $\begin{array}{l}\text { Share women } \\
\text { in wage } \\
\text { employment }\end{array}$ & & $\begin{array}{l}\text { Fish stock } \\
\text { within safe } \\
\text { limits }\end{array}$ \\
\hline & Potable water & \multirow[t]{2}{*}{ TICS } & $\begin{array}{l}\text { Fix and mobile } \\
\text { lines per } 100 \mathrm{p} \text {. }\end{array}$ & \multirow[t]{2}{*}{ Freshwater } & $\begin{array}{l}\text { Presence of } \\
\text { faecal coliforms }\end{array}$ \\
\hline & $\begin{array}{l}\text { Access to energy } \\
\text { and services }\end{array}$ & & $\begin{array}{l}\text { Internet users } \\
\text { per } 100 \mathrm{p} .\end{array}$ & & $\begin{array}{l}\text { Biochemical } \\
\text { oxygen demand } \\
\text { BOD }\end{array}$ \\
\hline \multirow[t]{2}{*}{ Health } & $\begin{array}{l}\text { Under-five } \\
\text { mortality rate }\end{array}$ & Tourism & $\begin{array}{l}\text { Ratio residents } \\
\text { to tourists }\end{array}$ & \multirow[t]{4}{*}{ Biodiversity } & $\begin{array}{l}\text { Proportion of } \\
\text { area protected } \\
\text { by ecosystem }\end{array}$ \\
\hline & $\begin{array}{l}\text { Population with } \\
\text { access to health } \\
\text { care }(\%)\end{array}$ & \multirow[t]{3}{*}{ Energy use } & \multirow[t]{3}{*}{$\begin{array}{l}\text { Annual energy } \\
\text { consumption }\end{array}$} & & \multirow[t]{3}{*}{$\begin{array}{l}\text { Abundance of } \\
\text { selected key } \\
\text { species }\end{array}$} \\
\hline \multirow[t]{2}{*}{ Education } & $\begin{array}{l}\text { Net enrolment } \\
\text { rate in primary } \\
\text { education }\end{array}$ & & & & \\
\hline & Adult literacy rate & & & & \\
\hline
\end{tabular}

\subsection{Social indicators}

The indicators of the poverty theme showed that almost half of the population in the study region is below the national poverty line (Fig. 3). The poverty line is estimated according to the Monthly National Minimum Salary (MNMS), which is US\$150.00 approximately. The average income in the region is roughly

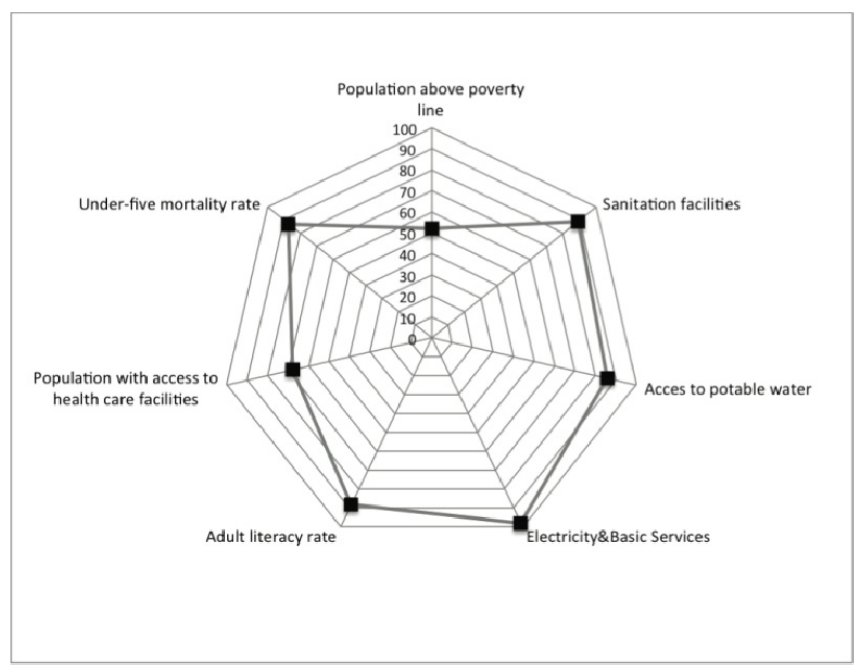

Figure 3: $\quad$ Social indicators. 
US\$300, but, people living above the MNMS do not necessarily have satisfactory remuneration. There was a marked inequality between gender incomes, where the men earn almost the double that of women. Women's opportunities to find labour, technical or professional positions are still restricted in Mexico and the study region data illustrated this fact.

Indicators related to access to services illustrated relatively high values. Most of the population have a proper sanitary facility, ranging from simple latrines to flush toilets; drinking water by public piped connections to houses; access to electricity and basic social services; telephone line -fix or cellular and a private television service. The number of telephone lines and cellular services has substantially increased in the last five years in the region and the country, despite that the cost of the service is significantly higher than in other countries with a similar development level. Public service television is limited to five channels; as a result, most of the population prefer to pay for a private service, which is monopolised by two main companies. The UN Commission for Sustainable Development proposed in 2007 an indicator related with the percentage of people with Internet access for international comparisons, the result observed in this evaluation was self-evident (Fig. 3).

The indicators related with the theme of health illustrated that the mortality of children under five years old was $12 \%$, which is greater of the $5 \%$ expected by the UN Millennium Development Goals Indicators [14]. This result is clearly related with the indicator of population with access to primary health care service, which was $68 \%$ of the total population (Fig. 3). It is important to state that this percentage is increasing gradually after the Mexican Government implemented a system for Popular Health Care, freely accessible to the population.

Education indicators showed values that evidence a limited progress toward sustainability. For adults ( $>15$ years old) illiteracy was $12 \%$, when the expected value according to the UN should be less than 5\%, reflecting the lack of accomplishment of the Education Secretary in extending literacy to rural regions. The average for the maximum education level among the population of the three towns was sixth degree, i.e. complete primary school. From the 6-12-year olds, total population, the net enrolment in primary school registered was $86 \%$, whereas the international goal of the sustainable development agenda is $100 \%$.

\subsection{Economic indicators}

The indicator of employment showed a high percentage of population in work (94\%), which is a good sign for the region (Fig. 4). It is important to note that Campeche State, (the region of study), has the lowest unemployment level out of 32 Mexican States. The number of women in waged occupation is acceptable $(80 \%)$ considering that the employment opportunities in the region are not abundant.

The percentage of the total population living in the region with Internet access was only $12 \%$ due to the internet distribution along the coastal corridor, even in the towns, being limited. Conversely, telephone and private television services are accessible to most of the region's population (Fig. 4). Both telephone and 
television services, are monopolised in Mexico and are overpriced, but provide modern telecommunications to urban and rural areas.

The ratio of local residents to tourists in the region was calculated for the whole year because the seasonal statistics were diffuse. The value was low and this may indicate a moderate pressure on the ecosystems and the socio-cultural resources of the small towns. This result could be particularly important prospectively for planning and management of the tourism activities; thus, tourism is an increasing strategy sector in the regional and national economy, justified as the contribution to the socioeconomic well-being of the resident population.

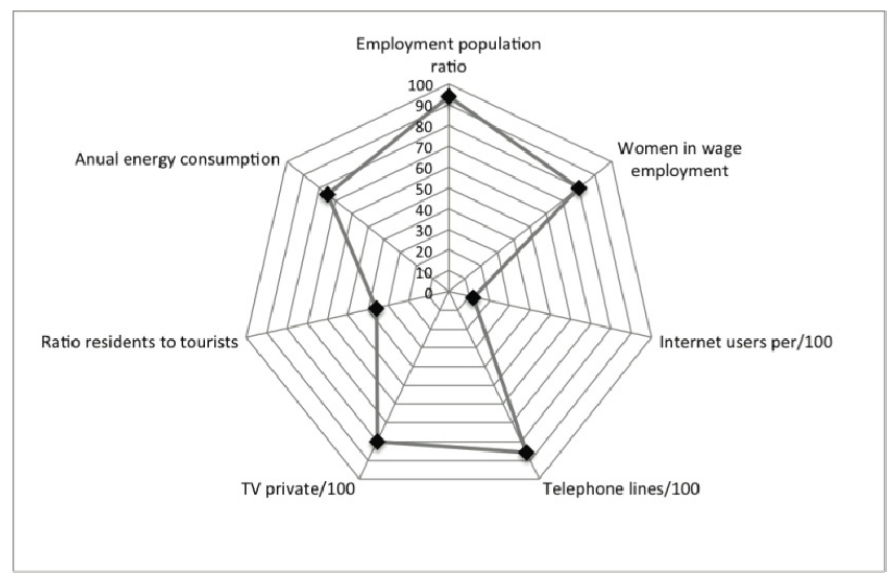

Figure 4: Economic indicators.

\subsection{Environmental indicators}

About half of the region studied is part of the "Laguna de Terminos" Natural Protected Area, which includes approximately $800 \mathrm{~km}^{2}$ of marine zone. The marine areas in the coastal corridor are closely associated to the internal ecosystems and are therefore essential to maintaining biodiversity and are also important for cultural activities, recreation, scientific research, etc. Important fisheries are present in the marine zone (e.g. sea bass, red snapper, octopus, swordfish, corvine, grouper, crab, shark, sea cucumber, mackerel), which represent the family livelihoods of fishermen. Most of the fish stocks are exploited within their level of maximum biological productivity (Fig. 5), but some species like the shrimp, octopus and sea cucumber are under temporal or permanent fishing prohibition $[15,16]$.

The indicator related to the presence of faecal coliforms was calculated in terms of the percentage of the total survey sites, where the levels of concentration of faecal coliforms were within the national and international standard [17]. From 48 sampling sites on the reef lagoon, estuary and river, $85 \%$ meet the recommended levels (Fig. 5). The sites where the presence of coliforms exceeded the standard were located close to the towns, this result is explicable 
because the domestic water discharges go directly into the water bodies; there is no a sewage system or an efficient treatment of the residual water before their final disposal. Diarrhoeal diseases are the major cause for morbidity and mortality in many developing countries, especially among children. A similar pattern was observed for BOD values, an indicator that measures the amount of oxygen consumed though the microbiological decomposition of organic material in water. The percentage of the total sampling sites with an acceptable level of BOD according to national and international standards was calculated (Fig. 5).

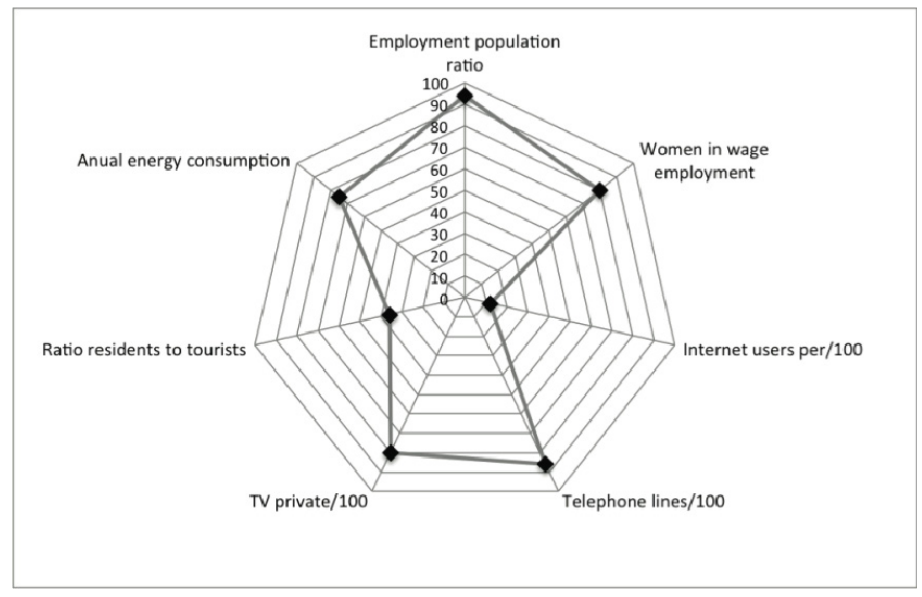

Figure 5: Environmental indicators.

The entire area of the ecosystems within the "Laguna de Terminos" NPA is legally protected. The coastal lagoon system is one of the biggest estuarine environments of the Gulf of Mexico; comprising numerous subsystems and critical habitats (e.g. fluvial flow systems, mangroves, seagrass). Among the key species present in the coastal corridor ecosystems were dolphins, sea turtles, mangroves, manatee, crocodiles, amphibians and aquatic birds. Most of these species are under threat or extinction risk. The two existing species of aquatic mammals in the region (100\%) and most of the species of aquatic reptiles $(93 \%)$ are under threat, including the three species of marine turtles which migrate to the coastal zone in the region studied, $30.3 \%$ of the amphibians, $39.7 \%$ of the fishes and $12.7 \%$ of the aquatic birds. The indicator value was calculated as a weighted average of the individual percentages of species under threat.

\section{Conclusions}

A case of study has been presented about the use of sustainability indicators framework and methodology for an integral diagnosis of the socioeconomic and environmental condition of a coastal region in Mexico. From past information and present data we diagnosed a social alienation derived from low incomes of the people, which affect the access to basic services like health care, education 
and communications. The economy is still based on fishing and agricultural activities, but is experiencing a rapid transition to tourism, activity that is perceived for residents, visitors, government authorities and stakeholders as the solution to the economic and social development problems. From environmental indicators results, we can consider that the degree of the ecosystems' health is relatively stable at the moment, but under risk of heavy pressure derived from touristic and urban activities.

From the local communities' perspective, the challenge is to maintain the necessary quantity and quality of environmental resources that the community depends on today and could sustain the tourist activity in the future. The present cultural and political idiosyncrasy, at both local and national level, makes the sustainability a difficult goal. In this assessment, there were some limitations mainly related with the availability and exchange of reliable and sufficient data, which in turn restricted the selection and design of the sustainability indicators. Even so, we got a basic understanding of the interactions between environmental, economic and sociocultural factors of the studied region. Decision makers might use this information and apply it to promote careful sustainable development planning and management.

\section{References}

[1] Instituto Nacional de Estadistica y Geografia INEGI. Anuario Estadistico de Campeche. Gobierno del Estado de Campeche, Mexico, 2012

[2] Ecologically Sustainable Development Working Groups. Ecologically sustainable development working group final report-tourism. Canberra, Australian Capital Territory: Australian Government Publishing Service, 1991.

[3] Richins, H. Environmental, cultural, economic and socio community sustainability: a framework for sustainable tourism in resort destinations. Environmental Development Sustainability 11, pp. 785-800, 2009.

[4] Warhurst, A. Sustainability indicators and sustainability performance management. Report to the project: Mining, Minerals and Sustainable Development (MMSD). International Institute for Environmental and Development (IIED). Warwick, England, 2002. http:77.iie.org /mmsd/mmsd_pdfs/sustainability indicators.pdf

[5] Kumar, R. S., Murty, H.R., Gupta, S.K. \& Dikshit, A.K. An overview of sustainability assessment methodologies. Ecological Indicators 9 pp. 189212, 2009.

[6] Spangenberg, J.H. Economic sustainability of the economy: concepts and indicators. International Journal of Sustainable Development 8, 47-64, 2005.

[7] Bell, S., \& Morse, S., Sustainability indicators measuring the immeasurable? Earthscan: London and Sterling, VA, pp 3-44, 2008.

[8] CONABIO and SEMARNAT. Cuarto Informe Nacional de Mexico al Convenio sobre Diversidad Biologica (CDB). Comision Nacional para el 
Conocimiento y Uso de la Biodiversidad and Secretaría del Medio Ambiente y Recursos Naturales, Mexico, 2009.

[9] IUCN. The IUCN Red List of Threatened Species. Version 2012.2. www.iucnredlist.org

[10] United Nations. Indicators of Sustainable Development Guidelines and Methodologies, Third Edition, United Nations, New York, 2007.

[11] INE and INEGI. Sustainable Development Indicators of Mexico. National Institute of Ecology and National Institute of Statistics, Geography and Informatics, Mexico, 2000.

[12] OECD. Environmental Indicators Toward Sustainable Development. Organization for Economic Cooperation and Development, Paris, 2001.

[13] Boggia, A. \& Cortina, C. Measuring sustainable development using a multi-criteria model: A case study. Journal of Environmental Management, 91, pp. 2301-2306, 2010.

[14] United Nations Millennium Declaration. Report of the Secretary General on the work of the Organization, New York, 2006. http://mdgs.un.org /unsd/mdg/Default.aspx.

[15] FAO yearbook. Fishery and aquaculture Statistics. Roma, FAO, 2010.

[16] SAGARPA. Secretaría de Agricultura, Ganadería, Desarrollo Rural, Pesca y Alimentación. Comisión Nacional de Acuacultura y Pesca. Epocas y zonas de veda de especies declaradas en veda. Gobierno de Mexico, 2010.

[17] WHO. World Health Organization. Guidelines for drinking-water quality. WHO, Geneva, 2011. 